Z. Klin. Chem. Klin. Biochem.

12. Jg. 1974 , S. $282-286$

\title{
Simultaneous Colorimetric Determination of Cholesterol and Triglycerides in Serum with a Dual- Channel AutoAnalyzer
}

\author{
By B. Köhring and R. Kattermann
}

Abteilung für Klin. Chemie, Medizinische Klinik und Poliklinik der Universität Göttingen

(Eingegangen am 20. Juli 1973/25. Januar 1974)

A simultaneous, semi-automated method for the determination of cholesterol and triglycerides in serum is presented. The procedure is based upon colorimetric reactions with a 1:10-isopropanol extract of $0.5 \mathrm{ml}$ serum. Both parameters can be analyzed with an output of $30 \mathrm{samples} / \mathrm{h}$ in a dual-channel AutoAnalyzer. The flow systems and the preparation of several reagents were improved and simplified as compared with known procedures. While the precision in subsequent analyses was $3.5 . \% \mathrm{CV}$ for both methods it was $4.4 \%$ for cholesterol and $5.6 \%$ for trigly cerides from day to day. Good accuracy could be confirmed with different control sera and by comparison with reference methods. The normal range measured on 210 healthy volunteers was $2.52-7.34 \mathrm{mmol} / 1$ for cholesterol and 0.16 $2.48 \mathrm{mmol} / \mathrm{l}$ for triglycerides with no consideration for age and sex.

Es wird über eine teilmechanisierte, simultane Bestimmung von Cholesterin und Triglyceriden im Serum berichtet. Das Verfahren beruht auf kolorimetrischen Reaktionen mit einem 1:10-Isopropanol-Extrakt aus 0,5 ml Serum. Beide Parameter können mit einer Frequenz von 30 Proben/h an einem 2-Kanal-AutoAnalyzer bestimmt werden. Gegenüber den herkömmlichen Methoden wurden die Fließschemata und die Herstellung verschiedener Reagenzien verbessert und vereinfacht. Die Präzision in der Serie lag für beide Methoden bei einem VK von 3,5\%. Die Präzision von Tag zu Tag zeigte einen VK von 4,4\% für Cholesterin und 5,6\% für Triglyceride. Die Richtigkeit der Methode konnte mit verschiedenen Kontroll-Seren und durch Vergleich mit Referenzmethoden bestätigt werden. Der an 210 stoffwechselgesunden Probanden gemessene Normalbereich erstreckte sich von 2,52-7,34 mmol/1 für Cholesterin und von $0,16-2,48 \mathrm{mmol} / 1$ für Triglyceride ohne Berücksichtigung von Lebensalter und Geschlecht.

It is widely accepted today that a combined determination of cholesterol and triglycerides in serum is the simplest and most reliable way to detect hyperlipidemia in man $(1,2)$. A variety of manual methods exists for both serum constituents which cannot be mentioned

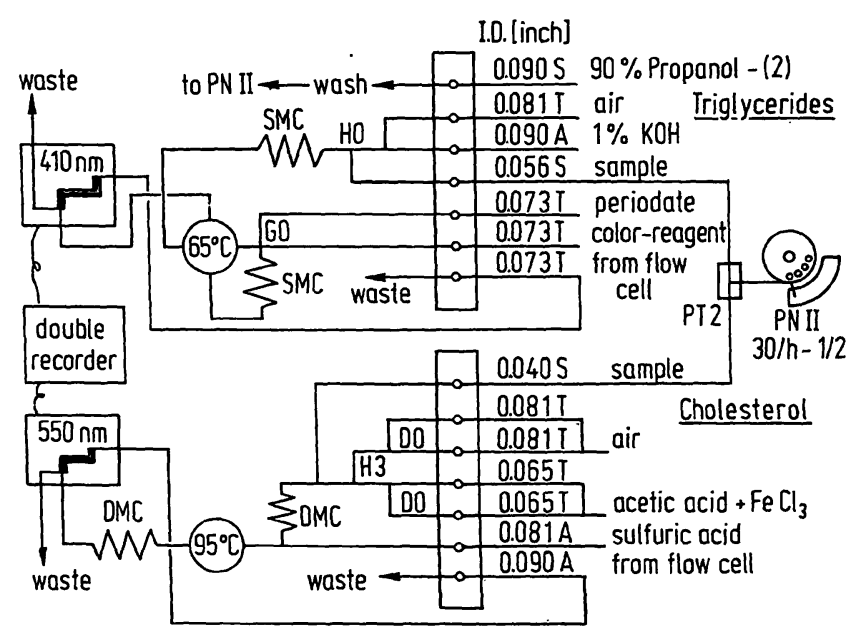

Fig. 1. Autoanalyzer flow-system for the simultaneous, colorimetric determination of cholesterol and triglycerides in an adsorbent-treated isopropanol extract of serum: Different tube qualities were used: $T=$ normal tygon tube, $A=$ Acidflex tube, $S=$ solvaflex tube

For further details - see methods. in detail here. However, it should be pointed out that very little information exists about suitable, simultaneous methods for the determination of these two important parameters of lipid metabolism. During recent years our laboratory was confronted with increasing numbers of cholesterol and triglyceride requests, which is in good agreement with the reports from other laboratories (3). We therefore developed a combination of a colorimetric cholesterol and triglyceride determination in isopropanol extracts of serum using a simple dualchannel AutoAnalyzer system (fig. 1).

\section{Methods}

The semi-automated procedure described here was based on the work of Kessler and Lederer (4) on triglyceride determination. Since we used a normal $15 \mathrm{~mm}$-light-path-colorimeter instead of a fluorometer, only a 1:10 dilution in the serum extraction could be applied.

\section{Extraction of serum}

$500 \mu 1$ serum are delivered with $4.5 \mathrm{ml}$ isopropanol (Merck Nr. 9634) with the aid of an automatic pipet (Dilumatik, B. Braun, Melsungen/Germany) into a plastic tube. For the aspiration of the sample we use a glass tube $(150 \mathrm{~mm}$ length, $2 \mathrm{~mm}$ internal diameter), the tip of which is cleaned daily from minor protein precipitates. 


\section{Adsorption step}

$0.5 \mathrm{~g}$ of a heat-activated adsorbent mixture described below are added to each sample extract. The tubes are capped and the contents are vigorously mixed for $\mathbf{3 0} \mathrm{min}$ in a mechanical, horizontal shaking machine. Thereafter, the protein precipitate and the adsorbent mass are centrifuged down $(10 \mathrm{~min} /$

$3000 \mathrm{rpm}$ ) and part of the supernatant, purified isopropanol extract is delivered into sample cups. The whole supernatant fluid is sufficient for double determinations of both parameters.

\section{Preparation of the adsorbent mixture}

Silicagel (Merck-No. 7739)

Fuller earth (Serva-No. 21940)

Calcium hydroxide (Merck-No. 2047)

Copper sulfate anhydrous (Merck-No. 2790)

The four constituents are thorougly mixed by hand and heated overnight at $130^{\circ} \mathrm{C}$. When stored in a desiccator the mixture remains active for several weeks. It has been found useful to check each new lot especially for the capacity of glucose elimination. For this purpose, the triglyceride value of a normal pool serum is compared with that of the same serum enriched with glucose up to $27.5 \mathrm{mmol} / \mathrm{l}$. If the latter value exceeds the former by more than $15 \%$, the adsorbent mixture has to be reactivated or prepared freshly from its constituents. When checked in this way, the original adsorbent mixture of Kessler and Lederer (4) was not satisfactory in our method with respect to glucose interference. Therefore the "zeolite mixture" (Technicon-Nr. T 11-0375) prepared according to the above mentioned authors cannot be utilized.

\section{Cholesterol determination}

The procedure was based on the work of Block et al (5) with respect to the suggestions for the determination of cholesterol esters made by Siegel and Bowdoin (6). In our system the ferric chloride color reagent and concentrated sulfuric acid are aspirated by separate tubes into the system (see fig. 1). By this way the very tedious and somewhat dangerous preparation of the color reagent (see Technicon N-24a-method) can be avoided.

\section{Color reagent}

To an original bottle of 2.5 liters of glacial acetic acid (Merck No. 90062) is added $1.3 \mathrm{~g}$ of ferric chloride sublimed (Riedel No. 1321) which easily dissolves overnight at room temperature. The color reagent is pumped through normal tygon tubings which are changed after 15-20 hours of operation (approximately twice in a week). Concentrated sulfuric acid (Merck No. 731) is aspirated separately by an acidflex tube (fig. 1). Most connections are made by glass tubes and the whole cholesterol system is put on an acid proof tray for the purpose of security. As a reference method the digitonin fourstep-procedure of Sperry and Webb (7) was employed.

\section{Trigly ceride determination}

As suggested by Fletcher (8) the fluorometric measurement of the Hantzsch-reaction product in the method of Kessler and Lederer (4) can be replaced by a colorimetric determination at $400-420 \mathrm{~nm}$ without running a blank value. In our system the manifold was simplified and the tube diameters reduced (see fig. 1). Thereîre the following reagents have to be used:

Saponification reagent: Dissolve $10 \mathrm{~g}$ of potassium hydroxide (Merck No. 5033) in $250 \mathrm{ml}$ water and mix with $750 \mathrm{ml}$ of isopropanol.

Periodic acid reagent: Dissolve $5.35 \mathrm{~g}$ of sodium periodate (Merck No. 6597) in $880 \mathrm{ml}$ water with addition of $120 \mathrm{ml}$ of glacial acetic acid.

Color reagent: Dissolve $130 \mathrm{~g}$ of ammonium acetate (Merck No. 1116) in $1000 \mathrm{ml}$ of water on a magnetic stirrer. The $\mathrm{pH}$ is adjusted to 6.0 with glacial acetic acid. Then $7.5 \mathrm{ml}$ of acetylacetone (Merck No. 9600) and $25 \mathrm{ml}$ of isopropanol are added.
For reference, the enzymatic method of Eggstein and Kreutz (9) as modified by Schmidt and v. Dahl (10) was used.

\section{Combined-Standards}

$1000 \mathrm{mg}$ of cholesterol (Merck No. 24644) and $1000 \mathrm{mg}$ of triolein (Merck No. 7011, olive oil p. a.) are separately dissolved as stock standards in $100 \mathrm{ml}$ of isopropanol. Working standards are prepared with increasing volumes (1.0$7.5 \mathrm{ml}$ ) of the stock and dilution to $100 \mathrm{ml}$ with isopropanol. Specimens with lipid values above this range must be diluted with saline before the extraction step.

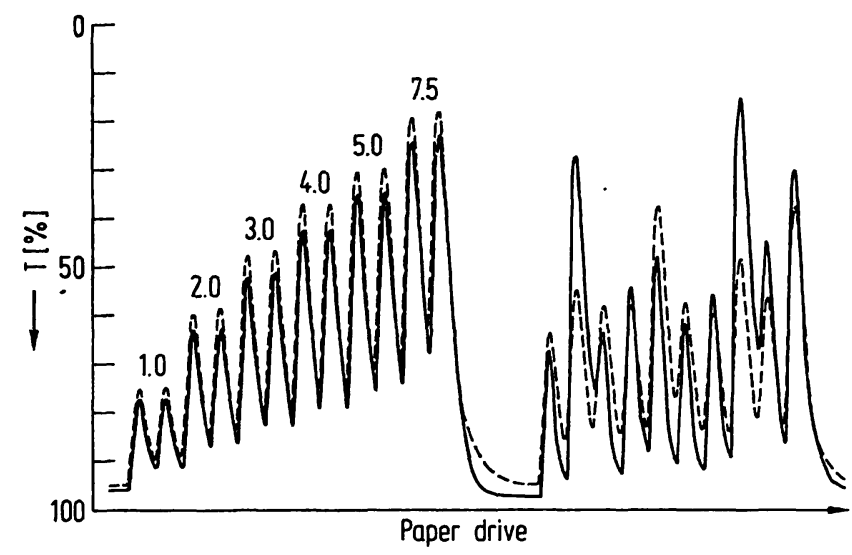

Fig. 2. Calibration curve (left) with combined standards from 1.00 to $7.50 \mathrm{~g} / l$, i. e. 2.6 to $19.4 \mathrm{mmol} / l$ for cholesterol $(--)$ and 1.1 to $8.1 \mathrm{mmol} / 1$ for triglycerides (Colorimetric determinations at 580 and $410 \mathrm{~nm}$ in two $15 \mathrm{~mm}$ light-path colorimeters. In addition, demonstration of 10 normal or pathological serum extracts (right).

\section{Procedure}

Before setting the reagent baseline the triglyceride system is washed with demineralized water (periodic acid and color reagent tubes) or with $90 \%$ isopropanol (all other tubes). Standards and serum extracts'are picked up with a frequency of 30 samples/h (1:2) with $90 \%$ isopropanol in the washing receptacle. While cholesterol values are taken directly from the calibration curve, trigly ceride values have to be corrected for the blank color in nonsaponified sample extracts. In general, these blank values are fairly constant between 0.1 to $0.2 \mathrm{mmol} / \mathrm{l}$ when the extraction is carried out on fresh serum. This was established by comparison with enzy matic triglyceride values. For practical purposes we found it convenient to shift the triglyceride calibration curve according the regression formula based on these enzymatic values.

\section{Results and discussion}

\section{General aspects (Tab. 1)}

The simultaneous determination of cholesterol and triglycerides described above has now been operating for about two years without any fundamental troubles. In our laboratory it has replaced the unreliable and cumbersome manual determination of total lipids by the sulfophosphovanilline reaction and the direct estimation of cholesterol by the AutoAnalyzer according to Levine et al (11). The latter method suffers from several disadvantages: The dangerous preparation of the color reagent, the rather frequent clogging by serum at the entry to the reagent stream (HO-fitting), the problem of dissolving high standards in acetic acid and the bilirubin interference. In contrast, in our simultaneous system the danger from reagents is 
Tab. 1. General aspects of the simultaneous, colorimetric cholesterol-triglyceride determination in comparison to other AutoAnalyzer methods $(4,5,6,11,15,16,17,22)$.

\begin{tabular}{|c|c|c|}
\hline & Cholesterol & Triglycerides \\
\hline Flow system & $\begin{array}{l}\text { Glass connections wherever possible. Proportioning } \\
\text { pump and oil bath on acid proof tray }\end{array}$ & $\begin{array}{l}\text { Simplified manifold with decreased reagent consump- } \\
\text { tion. Peaks in phase with the cholesterol system }\end{array}$ \\
\hline Modified reagents & $\begin{array}{l}\text { Separate addition of ferric chloride in glacial } \\
\text { acetic acid and sulfuric acid }\end{array}$ & $\begin{array}{l}\text { Increased concentration of } \mathrm{KOH} \text { with reduced } \\
\text { saponifying time in a double mixing coil }\end{array}$ \\
\hline $\begin{array}{l}\text { Improved adsorbent } \\
\text { mixture }\end{array}$ & $\begin{array}{l}\text { Elimination of bilirubin and other chromogens } \\
\text { causing falsely elevated cholesterol values }\end{array}$ & $\begin{array}{l}\text { Elimination of glucose interference up to } \\
27 \text { mmol/1 by increased copper sulfate-calcium } \\
\text { hydroxide concentration }\end{array}$ \\
\hline $\begin{array}{l}\text { Measurement } \\
\text { and evaluation }\end{array}$ & $\begin{array}{l}\text { Equal color intensity for free and esterified } \\
\text { cholesterol. Values read directly off a calibration } \\
\text { curve with colesterol standards in isopropanol }\end{array}$ & $\begin{array}{l}\text { Colorimetry with fairly constant, low serum blanks } \\
\text { instead of fluorometry. Values read off a corrected } \\
\text { calibration curve based on triolein standards in } \\
\text { isopropanol }\end{array}$ \\
\hline Costs of reagents & approx. DM 0.08/analysis & approx. DM 0.05/analy sis \\
\hline
\end{tabular}

minimized, the standards can be easily dissolved in isopropanol and the bilirubin effect is eliminated (see below).

The reagent costs for both systems are remarkably low (see tab. 1), and the effective sample output 100 samples from each channel in about 4 hours seems sufficient for the common hospital laboratory. It should be pointed out, that the whole system can be put together with the normal equipment of the first AutoAnalyzer generation and that there is no need for a fluorometer.

Efficiency of the adsorbent mixture in the triglyceride determination

In the fluorometric procedure of Kessler and Lederer (4) $2.0 \mathrm{~g}$ zeolite mixture are added to the serum extract $(1: 20)$ in order to eliminate the interfering phospholipids, glycerol, glucose and other substances. Since we reduced the adsorbent mass to $0.5 \mathrm{~g}$ we had to increase the proportion of copper sulfate and calcium hydroxide. Moreover, the adsorbent is obviously more effective when it is kept in contact with the serum extract for a longer time. For practical purposes, in our laboratory all samples are extracted at the end of a working day, shaken with adsorbent and allowed to stand at $4^{\circ} \mathrm{C}$ for about 20 hours until the next morning. Yet, under these conditions, free glycerol is not fully removed, an observation also made by Boberg et al (12). A valuable side-effect of the adsorbent treatment is the removal of any bilirubin interference from the determination of cholesterol. By adding increasing amounts of bilirubin to normal pooled serum according the method of Schellong and Wende (13) we got virtually no increase of the corresponding cholesterol values - in contrast to the results of the direct Liebermann-Burchard reaction (11).

Another possibility for removing the interfering substances in the triglyceride determination is the extraction with isopropanol - nonane and consecutive phase- separation according to Royer and Ko (14). When applying this rather difficult manual procedure we got excellent triglyceride values in comparison to the enzymatic method. Unfortunately, it is not possible to determine cholesterol in the nonane extract with any of the known methods. Therefore, we made no further efforts to establish the nonane-extraction in our simultaneous system. It should be mentioned here, that Björksten (15) has realized a fully automated isopropanol-nonane extraction and triglyceride determination with the aid of an AutoAnalyzer system.

\section{Precision (Tab. 2)}

In general, automated methods are characterized by better reproducibility when compared with manual procedures. This could be confirmed by replicate determinations of a pooled serum extract which resulted in a coefficient of variation of $0.74 \%$ for cholesterol and $1.70 \%$ for triglycerides (tab. 2). These values increase to about $3 \%$ when the extraction and adsorption steps are included. Finally, a normal and pathological pool serum was prepared, stored frozen, and analyzed

Tab. 2. Precision of the simultaneous, colorimetric determination of cholesterol and triglycerides under different conditions. The coefficients of variation are constantly better for the cholesterol determination.

\begin{tabular}{|c|c|c|c|}
\hline \multicolumn{2}{|c|}{$\begin{array}{l}\text { Precision } \\
\text { (Coefficients of variation) }\end{array}$} & Cholesterol & Triglycerides \\
\hline \multicolumn{2}{|c|}{$\begin{array}{l}\text { Serial determination without } \\
\text { extraction }(n=25)\end{array}$} & $0.74 \%$ & $1.70 \%$ \\
\hline \multicolumn{2}{|c|}{$\begin{array}{l}\text { Serial determination with } \\
\text { extraction }(n=20)\end{array}$} & $2.97 \%$ & $3.44 \%$ \\
\hline \multirow{2}{*}{$\begin{array}{l}\text { Precision } \\
\text { from } \\
\text { day } \\
\text { to day }\end{array}$} & $\begin{array}{l}\text { Normal range } \\
(n=60)\end{array}$ & $4.43 \%$ & $5.67 \%$ \\
\hline & $\begin{array}{l}\text { Pathological range } \\
(n=60)\end{array}$ & $3.02 \%$ & $3.08 \%$ \\
\hline
\end{tabular}


over twelve weeks. The precision "from day to day" was apparently somewhat worse for the normal range, in contrast to the pathological serum for which the coefficients of variation were found to be about $3 \%$ for both parameters. In all other cases the cholesterol method seemed to be superior to the triglyceride method. Nevertheless, the precision obtained with our simultaneous method can be regarded as sufficient for the detection of hyperlipidemia.

\section{Accu racy (Tab. 3)}

With three different control sera a mean deviation from the authentic values of $-0.7 \%$ for cholesterol and of $1 \%$ for triglycerides was observed. It should be mentioned, however, that in the case of control serum the varying amount of free glycerol must be taken into account. That seems to be the reason why $M c$ Lellan (16) runs a blank only on the control serum before each run of triglycerides. When 60 specimens with cholesterol values between 2.5 and $15.0 \mathrm{mmol} / 1$ were determined both by the AutoAnalyzer and the reference method (7) the following equation was calculated:

$y=0.88 x+0.67 ; \quad r=0.98 ; n=60$

This means that a rather good agreement of both methods exists in the normal range, while specimens with high cholesterol levels must be diluted for accurate determinations. In another series the triglyceride values were compared with the results of the enzymatic method (10). A close correlation could be found, which obeys the following equation:

$y=0.97 x+0.10 ; \quad r=0.98 ; n=96$

Tab. 3. Accuracy of the simultaneous method checked by the reference values of three different control sera. The results were calculated as the mean of 10 to 20 determinations made on different days.

\begin{tabular}{lllll}
\hline & $\begin{array}{l}\text { Cholesterol } \\
(\mathrm{mmol} / \mathrm{l})\end{array}$ & \multicolumn{3}{c}{$\begin{array}{l}\text { Triglycerides } \\
(\mathrm{mmol} / \mathrm{l})\end{array}$} \\
Control serum & $\begin{array}{l}\text { reference } \\
\text { value }\end{array}$ & $\begin{array}{l}\text { value } \\
\text { found }\end{array}$ & $\begin{array}{l}\text { reference } \\
\text { value }\end{array}$ & $\begin{array}{l}\text { value } \\
\text { found }\end{array}$ \\
\hline $\begin{array}{l}\text { Normal Hyland } \\
(\mathrm{n}=20)\end{array}$ & 4.64 & $\begin{array}{l}4.62 \\
(-0.7 \%)\end{array}$ & 0.92 & $\begin{array}{l}0.96 \\
(+5 \%)\end{array}$ \\
$\begin{array}{l}\text { Monitrol Dade } \\
(\mathrm{n}=10)\end{array}$ & 4.13 & $\begin{array}{l}4.38 \\
(+6.3 \%)\end{array}$ & 0.91 & $\begin{array}{l}0.92 \\
(+1.3 \%)\end{array}$ \\
$\begin{array}{l}\text { Precilip } \\
\text { Boehringer } \\
(n=10)\end{array}$ & 4.80 & $\begin{array}{l}4.41 \\
(-7.8 \%)\end{array}$ & 1.58 & $\begin{array}{l}1.44 \\
(-9.4 \%)\end{array}$ \\
\hline
\end{tabular}

This good agreement could only be achieved by subtracting a blank from the total triglyceride value (see methods). In a recent publication however, Rautela et al (17) gave arguments against the determination of blank values in the fluorometric method.

\section{Normal values}

Cholesterol and triglyceride analyses were performed in blood specimens drawn after an overnight fast from 210 healthy adults ranging from 18 to 65 years. The normal ranges calculated with the assumption of a normal distribution were

Triglycerides: $0.16-2.48 \mathrm{mmol} / 1(15-228 \mathrm{mg} / 100 \mathrm{ml})$ Cholesterol: $\quad 2.52-7.34 \mathrm{mmol} / \mathrm{l}(97-284 \mathrm{mg} / 100 \mathrm{ml})$

These values are in agreement with the results of other authors $(1,2,18,19)$ the wide scattering representing the heterogeneity of our population with regard to sex and age.

Finally, it must be noted here, that the enzymatic triglyceride determination has been successfully applied to discrete sampling machines $(20,21)$. As pointed out by Da Fonseca-Wollheim (3) the manual enzymatic procedure can be considerably economized with the aid of a microliter equipment and by means of a digital photometer. In the meantime, the application of the enzymatic triglyceride estimation to the AutoAnalyzer system has also been described (22). So far, we have no experience with this method which could principally be combined with a direct cholesterol determination. Certainly, in all these systems the reagent costs are considerably higher than in our method. This will also be true for the enzymatic cholesterol determination by means of cholesterol oxidase from Nocardia erythropolis.

In our opinion, the simultaneous cholesterol-triglyceride method described here has the features of a screening method, which can certainly differentiate between normal and markedly elevated serum lipid levels. The latter are confirmed, in our laboratory, by manual enzymatic triglyceride, cholesterol and phospholipid determinations, followed by the typing procedure based on lipoprotein electrophoresis in agarose gel according to Fredrickson et al (1). The question remains, whether our simultaneous method has also diagnostic relevance in the case of slightly elevated lipid levels, which frequently occur in patients with coronary heart disease and/or myocardial infarction (23) and are of great importance especially in the field of health screening (24). The experience with our method made in a study with 500 first-degree relatives of diabetics will be reported elsewhere. 


\section{References}

1. Fredrickson, D. S., Levy, R. I. \& Lees, P. S. (1967), N. Engl. J. Med. 276, 94-103.

2. Schlierf, G., Weinans, G., Reinheimer, W. \& Kahlke, W. (1972), Deut. Med. Wochenschr. 97, 1371-1375.

3. Da Fonseca-Wollheim, F. (1973), Ärztl. Lab. 19, 65-74.

4. Kessler, G. \& Lederer, H. (1965), in Automation in Analytical Chemistry (Techn. Corp. Hrsg.), S. 341, New York.

5. Block, W. D.; Jarret, K. J. \& Levine, J. B. (1966), Clin. Chem. 12, 681-689.

6. Siegel, A. L. \& Bowdoin, B. C. (1971), Clin. Chem. 17, 229-230.

7. Sperry, W. M. \& Webb, M. (1950), J. Biol. Chem. 187, 97110.

8. Fletcher, M. J. (1968), Clin. Chim. Acta 22, 393-397.

9. Eggstein, M. \& Kreutz, F. W. (1966), Klin. Wochenschr. 44, 262-267.

10. Schmidt, F. H. \& von Dahl, K. (1968), diese Z. 6, 156159.

11. Levine, J., Morgenstern, S. \& Vlastelica, D. (1968), in Automation in Analytical Chemistry (Technicon Corp. Hrsg.) S. 25, New York.

12. Boberg, J., Carlson, L. A. \& Freyschuss, U. (1972), Eur. J. Clin. Invest. 2, 123-132.

13. Schellon, G. \& Wende, U. (1960), Klin. Wochenschr. 38 , 703-707.

14. Royer, K. \& Ko, H. (1969), Anal. Biochem. 29, 405-416.

15. Björksten, F. (1972), Clin. Chim. Acta 40, 143-152.

16. McLellan (1971), Clin. Chem. 17, 535-537.

17. Rautela, G. S., Slater, S. \& Arvan, D. A. (1973), Clin. Chem. 19, 1193-1195.

18. Hartmann, G. \& Werner, M. (1970), in: Die Hyperlipidämien in Klinik und Praxis (Hartmann, G. \& Wyss, F. ed.), S. 39, Verilag H. Huber, Bern.

19. Jahnke, K. \& Herberg, M. (1969), Diagnostik 2, 305308.

20. van Oers, R., Scholtis, R., Schmidt, N., van de Calseyde, J. \& Kuypers, A. (1971), diese Z. 9, 516-519.

21. Schmidt, F. H., Schmidt, G., Dahl, K. v. \& Stork, H. (1972), diese Ż. 10, 160-163.

22. Fickel, K. \& Müller, J. D. (1973), Technicon-Nächrichten, Oktober 1973, 4-7.

23. Goldstein, J. L., Hazzard, W. R., Schrott, H. G., Bierman, E. L. \& Motulsky, A. G. (1973), J. Clin. Invest. 52, 1533-1543.

24. Kattermann, R. (1973), Diagnostik 6, 124-127.

Prof. Dr. Kattermann

Abt. für Klin. Chemie

Medizinische Klinik und Poliklinik der Universität Göttingen

D 34 Göttingen, Humboldtallee 1 